\title{
21. Yüzyıl Becerileri Perspektifinden Tarih Eğitiminin Yönü
}

\author{
SIBEL YALI* \\ ataman_si@yahoo.com \\ ORCID ID: 0000-0002-1435-3726
}

Öz: Bu çalışmada, Kanada, İngiltere, Avustralya ve ABD gibi refah seviyesi yüksek ülkeler ile Türkiye'deki güncel tarih eğitim müfredatlarna 21. yüzyll becerileri perspektifinden incelenmiş; tarih eğitiminin konjonktüre göre nasıl bir değişim gösterdiği tespit edilmeye çalışılmıştır. Bu kapsamda, 21. yüzyıl becerileri hakkında genel bir çerçeve sunulmuş, sonrasında bu yaklaşımın tarih eğitimindeki yansımaları üzerinde durulmuştur. Çalışmanın son bölümünde çalışmaya konu olan ülkeler ile Türkiye tarih eğitimi pratiklerine yer verilerek bir yorum geliştirilmeye çalışılmıştır. Milenyumla birlikte özellikle refah düzeyi yüksek ülkelerde tarih eğitimi kazanımlarının eleştirel düşünme ve problem çözme becerileri ile ilişkilendirildiği; tarihsel olaylara yaklaşımda çok perspektifliliğin geliştirildiği ve kültürel mirasın ortak yönlerinin takdir edilmesi üzere çalışıldığı görülmektedir. Bu bağlamda Kanada, Avustralya, Ingiltere ve Amerika'daki tarih ve sosyal bilgiler dersleri için hazırlanan güncel müfredatlar konu özelinde perspektif vermektedir. Türkiye pratikleri konusunda ise henüz yol alınması gerektiği söylenebilir.

Anahtar kelimeler: Tarih eğitimi, Müfredatlar, Eğitim politikaları, 21. yüzyıl becerileri

\section{Giriş ve Kavramsal Çerçeve}

Geçtiğimiz son 30 yıl içinde insanlık toplumsal, ekonomik ve teknolojik alanda çok hızlı bir değişim sürecinden geçti. Bu değişim hem ekonomik sektör ve trendleri hem de öğrencileri iş hayatına hazırlayan eğitim sistemlerini arz ve talep açısından etkiledi. Özellikle 1980'lerden itibaren, bu talepleri karşılamaya yönelik atılması gereken adımlar konusunda bir dizi temel beceri ve uygulama stratejilerini tanımlayan birçok rapor yayınladı.

Eğitim politikalarına bu perspektiften bakıldığında eğitim programlarının genel anlamda bu raporlarda işaret edilen unsurlarca ele alındığg görülüyor. Bu raporlarda öne çıkan unsurlar öğrenme ve inovasyon, dijital okuryazarlık ve yaşam becerileri ana başlıkları ile özetlenebilir. 21. yüzyıl becerileri ${ }^{1}$ olarak ifade edilen

\footnotetext{
* Doktora Öğrencisi, İstanbul Üniversitesi, Cerrahpaşa Lisansüstü Eğitim Enstitüsü.

${ }^{1} 21$. yüzyıl becerileri P21 adı verilen bir kuruluşun adı olarak literatürde yer almaktadır. Alanyazında buna benzer 30 kadar model bulunmaktadır ancak P21 dahil birkaç modelin sosyal medyada sıklıkla kullanımı söz konusudur. Metin içeriğinde yer alan 21. yüzyıl becerileri terimi ile bir kurum tarafından hazırlanan modelin tarifinden ziyade alanyazındaki genel kullanıma referans verilmektedir.
} 
bu unsurların ana çerçevesini Dünya Bankası, Dünya Ekonomik Forumu, OECD ve Avrupa Konseyi gibi ulusüstü kurumlar tarafından yayınlanan iş dünyasının eğitim beklentilerine ilişkin tavsiye ve önceliklerin belirlediği söylenebilir.

Makalede bu raporlarla altı çizilen problem çözme, eleştirel düşünme, dijital okuryazarlık becerileri ile birlikte çözüm geliştirme gibi becerilerin tarih müfredatlarında yer alıp almadığı sorusuna bir cevap aranmıştır. Bu soruya yanıt verebilmek amacıyla refah düzeyi yüksek olarak kabul edilen Kanada, İngiltere, ABD ve Avustralya'nın ulusal tarih ve sosyal bilgiler müfredat içeriklerine de bakılmıştır. Çalışmanın girizgahında 21. yüzyıl becerileri hakkında okuyucuya genel bir özet sunulmuş; daha sonra bu yaklaşımın tarih eğitimindeki yansımaları üzerinde durulmuştur. Son bölümde çalışmaya temel olan ülkelerin tarih eğitimi pratikleri ile Türkiye örneğine yer verilmiştir.

Bu çerçevede yürütülen ulusüstü projelerin çıtıtırı paradigma değişimi konusunda perspektif vermektedir.

\section{P21: 21. Yïzyıl Becerileri Ortaklı̆̆ı}

P21 Projesi, ${ }^{2} 33$ kurumun desteklediği ve Amerika Birleşik Devletleri'nin 21 eyaletinde uygulandığ 1 stratejik bir eğitim girişimidir. Proje, 21. yy. becerilerinin kazandırılması için değerli bir örnek olarak görülmektedir. ${ }^{3}$ Bu örnek girişim, temel konuların ve 21. yüzyıl temalarının üzerine inşa edilen yaşam ve meslek, öğrenme ve yenilenme ile bilgi, medya ve teknoloji becerilerini ihtiva eder. $\mathrm{Bu}$ modeli destekleyecek sistemler ise ölçme ve değerlendirme, dersler ve müfredat, profesyonel yetiştirme ile öğrenme ortamlarıdır. Model, bir bireyin sahip olması gereken beceri ve yeterlikleri eleştirel düşünme, merak, işbirliği ve yaratıcılık kelimelerinin İngilizce karşılıklarının baş harflerini kullanarak 4C ile tanımlar.

\section{Dünya Bankası Perspektifi}

Dünya çapında politika yapıcıların gündeminin ilk sıralarında istihdam yaratmak ve üretkenliği artırmak konuları gelmektedir. Birleşmiş Milletler'in bir parçası olan Dünya Bankası, 2010 yılında yayınladığı Daha Fazla Işs ve Verimlilik İçin Becerileri Arttırma başlıklı raporunda bu konunun önemine dikkat çekmiştir. Bu raporda çocukların erken yaşta eğitime başlamaları, bütün öğrencilerin öğreniminin teşviki, iş dünyasının talep ettiği mesleklerle ilgili becerilerin geliştirilmesi, girişimcilik ve yenilikçiliğin desteklenmesi ile iş dünyasının talep ettiği beceri setlerinin oluşturulması gerekliliği dile getirilmiştir. Özellikle 2016 yılında yayınladığı yıllık raporunda Dünya Bankası iklim değişikliği, salgın hastalıklar ve göç konulu üç önemli global soruna işaret ederek bu problemleri çözebilmenin tek şartının insan sermayesinin geliştirilmesi koşuluna bağlı olduğuna vurgu yapmıştır. Kurum tarafından aynı yıl yayınlanan Dünya Kalkınma Göstergeleri başlıklı bir diğer raporda sürdürülebilir kalkınma hedefleri tanımlanmıștır. Bu alanlardan biri olarak belirlenen eğitim alanı için kapsamlı, adil, kaliteli eğitim ilkesi belir-

\footnotetext{
2 "P21".

${ }^{3}$ İsmail Gelen, "P21-Program ve Öğretimde 21. Yüzyıl Beceri Çerçeveleri”, Disiplinlerarası Eğitim Araştırmaları Dergisi (Journal of Interdisciplinary Educational Research), 1/2 (2017), s.15-29.
} 
lenmiş ve herkes için hayat boyu öğrenme firsatlarının teşvik edilmesi gerektiğine dikkat çekilmiştir.

\section{Avrupa Birliği Çerçeve Metni}

Avrupa Birliği tarafından bu kapsamda hazırlanan çalışmaların başında Hayat Boyu Öğrenme İçin Temel Yeterlilikler Çerçevesi (2006) gelmektedir. Bu çalışma kapsamında yaşam boyu öğrenme stratejisi bağlamında edinilmesi gereken beceri setlerinin yine 21. yüzyıl becerileri olarak ifade edilen kavramlarla eşleştiği görülmektedir. Çerçeve metinde yer alan bu becerilerin her biri yaratıcılık, problem çözme, eleştirel düşünme, karar alma, risk değerlendirme, duygu yönetimi temaları ile ilişkilendirilmiştir. Bu becerilerin pratik hayata geçirilebilmesi konusunda 2008 yılında 21. Yüzyıl İçin Yeterlilikleri Geliştirme: Okullarda Avrupa İşbirliği için Gündem kılavuzu yayınlanmıştır. Bu kılavuzda küreselleşme ile birlikte toplum yapısının çeşitlendiği, toplumsal ve küresel meselelerle birlikte mesleklerin de dönüştüğüne dikkat çekilmiş ve bu konuda atılacak adımlar için önerilerde bulunulmuştur.

$\mathrm{Bu}$ kılavuzun uygulamadaki yansımalarını ölçebilmek amacıyla 2012 yılında Avrupa'da Eğitim ve Öğretim Monitör araştırması yapılmıştır. Araştırma sonuçları kılavuzda önerilen beceri setlerinin geliştirilmesi konusunda çok fazla yol alınamadığını ortaya koymuştur. Bu şartları düzeltmek maksadıyla Avrupa Birliği tarafından sırasıyla Eğitim Üzerine Yeniden Düşünmek (2013), Eğitimin Gelişimi ve Modernizasyonu (2016) raporları ile Avrupa İçin Yeni Beceriler Ajandası (2016) yayınlanmıştır. Birlik tarafından pandemi etkisiyle bu yıl İş Piyasalarında Covid19 ve Beceriler başlığı altında yeni bir teknik rapor hazırlanmıştır. Bu raporda iş ve işçi bulma kurumlarının, e-öğrenme platformlarının, uluslararası enstitülerin ve araştırma kurumlarının performansı ortaya konulmaya çalışılmıştır.

\section{UNESCO Herkes İçin Eğitim Hareketi ve Eğitimin Geleceği İnisiyatifi}

UNESCO, 2014 yılında yayınladığı 37 C/4 başlıklı belgede sekiz yıllık orta vadeli stratejisini küresel, bölgesel ve ülke düzeylerinde eğitim, bilim, kültür, iletişim ve bilgi alanındaki eylemler oluşturur. 9 ana başlık altında toplanan Orta Vadeli Strateji Belgesi'ndeki bu eylem başlıkları şu şekilde tanımlanmıştır: ${ }^{4}$

- Üye Devletlerin herkes için ulaşılabilir, yüksek kaliteli ve kapsayıcı hayat boyu öğrenmeyi teşvik etmek amacıyla eğitim sistemleri geliştirmelerini desteklemek,

- Öğrencileri yaratıcı ve sorumlu küresel vatandaş olmak için güçlendirmek,

- Herkes için eğitimin (EFA) ilerletilmesi ve gelecekteki uluslararası eğitim gündemini şekillendirmek,

- Bilim, teknoloji ve yenilik sistemleri ve politikalarının ulusal, bölgesel ve küresel olarak güçlendirmek,

- Sürdürülebilir kalkınmaya yönelik kritik zorluklarla ilgili uluslararası bilimsel işbirliğini desteklemek,

\footnotetext{
4 "Medium-Term Strategy"
} 
- Kapsamlı sosyal gelişmeyi desteklemek: Kültürlerin birbiriyle yakınlaşması için kültürlerarası diyalog ile etik ilkeleri teşvik etmek,

- Mirasın korunması, geliştirilmesi ve iletilmesi konularında çalışmalar yapmak,

- Yaratıcıllğı ve kültürel ifadelerin çeşitliliğini teşvik etmek,

- İfade özgürlüğü, medya geliştirme ve bilgiye erişimi teşvik etmek.

$\mathrm{Bu}$ çerçevede atılan somut adımların ilki Herkes İçin Eğitim hareketi olmuştur. 90'lı yıllarda başlatılan bu hareket neticesinde istenen sonuçlar alınamayınca, program, ekonomi ve eğitim bağlantılı öngörüler doğrultusunda 2000 yılında revize edilmiştir. Dakar Eylem Çerçevesi'ne (2015) göre yapılan çalışmalar netice vermeye başlamıştır. Ancak bu çalışmaların küresel hedefler ve riskler bağlamında yetersiz olacağı varsayımından hareketle UNESCO tarafından geçtiğimiz yıl Ĕ̈itimin Geleceği İnisiyatifi oluşturulmuştur.

\section{OECD Sosyal İlerleme Projesi}

OECD, beşeri sermayenin beceriler ve yeterlilikler açısından geliştirilmesi ve sürdürülmesi konusundaki çalışmalarına 1990’lı yıllarda başlamış, bu çerçevede yetkinliklerin tanımı ve seçimi üzerine DeSeCo başlıklı bir proje yürütmüştür. 2005 yılında bu projenin çıktıları olarak sürdürülebilir kalkınma ve sosyal uyum için belirlenen faktörler ile birlikte bireylerin başarılı ve sorumlu bir yaşam sürmeleri ve toplumun bugünün ve geleceğin zorluklarıyla yüzleşmesi için sahip olacakları beceri ve yeterlilikler konulu bir rapor yayınlamıştır. Bu raporla birlikte OECD tarafından yayınlanan 2011 tarihli Strateji Belgesi, 2012 tarihli Daha İyi Beceriler, İsler ve Yaşamlar Belgesi ve 2015 yılında yayınlanan Sosyal İlerleme başlıklı raporlarda 21. yüzyıl becerileri doğrultusunda tanımlamalar yapıldığ 1 görülmektedir. OECD, 21. yüzyılda edinilmesi gerekli görülen becerileri bilişsel ve sosyal olmak üzere iki boyutta ele almaktadır. Bu çerçevede eleştirel düşünme, analiz etme, problem çözme ve yorumlama gibi bilgiyi kullanmaya dönük beceriler öğrencilerde geliştirilmesi gereken bilişsel boyutu oluştururken hedefe ulaşma, birlikte çalışma ve duyguları kontrol edebilme yetenekleri sosyal duygusal boyutu oluşturmaktadır.

\section{Dünya Ekonomik Forumu (WEF) Eğitim Vizyonu}

Forum tarafından, Eğitim için Yeni Vizyon başlığı ile 2015 yılında yayınlanan raporda 4. sanayi devriminin gereksinimlerini karşlayabilecek ve inovasyon temelli küresel ekonomi koşullarında ülkelerin ilerlemesine katkı sağlayacak entelektüel sermayenin yaratılmasının eğitim sektöründen geçtiğine işaret edilmiştir. 91 ülkede yapılan araştırmalar neticesinde, 21. yüzyılda gerekli görülen beceriler 3 ana kapsamda 16 toplam beceri seti olarak tespit edilmiştir. WEF, bu modelde öğrencilerde geliştirilmesi gereken üç önemli boyuta dikkat çeker. Bu boyutlar sırasıyla günlük görevler için temel okuryazarlıklar; karmaşık zorluklar için yetkinlikler ve değişen çevreye adaptasyon için kişisel özelliklerdir. Temel okuryazarlıklar, okuma, anlama ve yazılı dili kullanma; rakamları ve sembolleri kullanma; bilimselliğin ilkelerini kavrama; teknoloji tabanlı içerik kullanma ve oluşturma; finansın bileşenlerini anlama ve uygulama; insana özgü bilgiyi anlama becerileri olarak 
ifade edilmiştir. Yetkinlikler başlığı altında eleştirel düşünce, yaratıcılık, iletişim ve işbirliği gibi bilişsel yetkinlikler ele alınmıştır. Karakter özellikleri başlığı altında merak, girişkenlik, cesaret, uyum, liderlik, sosyal ve kültürel farkındalık kavramlarına yer verilmiştir. Modelde, tüm bu becerilerin hayat boyu öğrenme çerçevesi içinde geliştirilmesi gereğine işaret edilmektedir.

\section{Dünyada Tek Tipleşen Eğitim Sistemleri}

Genel anlamda Amerikan merkezli alan yazına ve gelişmelere paralel olarak birçok ülkede, henüz düşünce aşamasında olsa da ülkemizde "hesap veren okul ve öğretmen" beklentisi oluşmaya başlamıştır. Hesap veren okul ve öğretmen beklentisini tetikleyen durumlardan biri de 1995 yılında başlayan Matematik ve Fen Eğilimleri Araştırması (TIMMS) ve 2000 yılında başlayan Uluslararası Öğrenci Değerlendirme Programı (PISA) gibi küresel ölçekli değerlendirmelerdir. Küresel ölçekli bu değerlendirmelerden önce ülkeler birbirlerinin eğitim sistemlerinden ancak karşılaştırmalı eğitim alanı ölçeğinde ilgiliydiler. Bu süreç, eğitim sistemlerini yavaş yavaş birbirlerine benzeten dinamiklerden biridir. Küresel düzeyde ortaya konulan değerlendirme ölçütleri ülkelerin eğitim sistemlerini neye göre karşılaştırıyorsa eğitim sistemleri o alana odaklanmaya başladılar. Eğitimde amacın ne olması gerektiğini, neyin önemli olduğunu bu küresel sınav merkezleri ve onların öncelikleri belirlemeye başladı. Bugün içinden geçtiğimiz süreçte biz istesek de istemesek de buna karşı kararlı bir duruş göstermedikçe, yeni alternatifler ortaya çıkarmadıkça, farklı ülkelerdeki okullar, eğitim anlamında aynı renklere boyanıyor, bir nevi tek tip elbise giyiyorlar.

Eğitim sistemlerini tek tipleştiren etkenlerden biri de küresel ölçekte örgütlenmiş olan farklı disiplinlere ait topluluklardır. Matematik, tarih, dil vb. gibi farklı disiplinlere ait küresel örgütler düzenledikleri kongreler ve öğretim program önerileri gibi faaliyetlerle ülkeler farklı olsa da öğretim programlarını neredeyse aynılaştırmaktadirlar.

Ekonomik İşbirliği ve Kalkınma Örgütü (OECD), Dünya Bankası gibi ekonomi örgütleri; Avrupa Komisyonu bünyesinde örgütlü, Avrupa Eğitim Bilgi ağı gibi siyasal örgütlenmeler hazırladıkları raporlar ve araştırmalarla bir taraftan ulusal eğitim sistemlerine katkı verirken diğer taraftan aynılaşmalarına da yol açmaktadır. Örneğin OECD ve Dünya Bankasının eğitim alanında ürettiği çalışmalar, ulusal eğitim bakanlıkları tarafından yapılan çalışmalardan daha büyük etki yaratmaktadır. Ayrıca bu örgütlerin ekonomi temelli olmaları nedeniyle ulusal öğretim programlarında gittikçe ekonominin öncelikleri artmaktadır. Süreç böyle devam ederse eğitim kurumlarını ekonomi bakanlıklarına bağlama önerilerinin gelmesi uzak bir ihtimal gibi görünmemektedir. Örneğin, Dünya Ekonomi Forumunun $^{5}$ ortaya koyduğu "21. Yüzyıl Becerileri", tamamen iş dünyasının bireyden beklentilerinden oluşmaktadır. Bu örnekteki gibi iş dünyasının beklediği beceri setleri, eğitim alan yazınında son dönemlerde çıkan makalelerin başköşelerinde yer bulmaktadır. Eğitim alan yazına hâkimiyetini gün geçtikçe artıran, "homo economicus" ortaya çıkarmayı hedefleyen, eğitim dışı örgütlerin raporları

\footnotetext{
${ }^{5}$ OECD, “The Future of Education and Skills Education 2030", (Position Paper), 2018.
} 
ulusal eğitim programlarının amaçları ve uygulamaları üzerinde büyük etki oluşturmaktadirlar.

Okul dışı toplumun sınırlı insan anlayışı, amaç kaymasına neden olarak okulu, insanı bir bütün olarak geliştirme işlevinden uzaklaştırmaktadır. Bu alanda çözüm ancak eğitim alanında daha etkili araştırma ve raporlar yayımlamakla gerçekleşebilir. Sonuçta kaçınılmaz olarak bu alanda bilgi üreten ülke ve kurumlar sürecin öznesi durumda olurken diğerleri sürecin nesnesi durumunda kalmaya devam edeceklerdir.

\section{"21. Yüzyıl Becerileri" Yaklaşımının Tarih Eğitimine Yansımaları}

XIX. asrın ortalarından itibaren tarihyazımında meydana gelen gelişmeler tarih eğitiminde müfredatların ve geleneksel öğretim yöntemlerinin sorgulanmasını da beraberinde getirmiştir. Smith, Bloch ve Braudel gibi tarihçiler tarihyazımına iktisadi, coğrafi ve sosyo-psikolojik perspektifler kazandırmışlardır. Annales Okulu'nun "insan faaliyetlerinin tamamına değinen bir tarih" önermesi tarihyazımına bu anlamda önemli bir katkı sağlamıştır. Postmodernist tarihçilerin geleneksel tarihyazımının o vakte kadar hiç değinmediği alanlarda araştırma yapmaları ve sessiz kalmış kesimlerin varlığına ilişkin ürün sunmaları da tarihyazımını ciddi şekilde zenginleştirmiştir. Savaş sonrası dönemde siyasal olguların değişmesi ile birlikte özellikle 1970'lerden itibaren tarih disiplininin ilgilendiği konuların kapsamı ile tarihin yararlandığı kaynakların çeşitliliği de farklılaşmıştır. ${ }^{6}$ Bu dönemde hem yeni tarihyazımları oluşmuş hem de klasik tarihyazım temaları parçacı bir bakış acısı ile ele alınmıştır.

Eğitim kuramcısı Piaget'nin etkisi ile 20. yüzyılın son çeyreğinden itibaren tarih eğitimi yaklaşımlarında önemli değişimler meydana gelmiştir. ${ }^{7}$ Örneğin, İngiltere merkezli School's Council History (13-16), The Humanities Curriculum, School's Council Place Time and Society (8-14) gibi projeler tarih eğitiminde öğretmenin rolü, konu ve malzeme seçimi ile dersin amaçları noktalarında alternatif yaklaşımların üretilebilmesine ön ayak olmuştur. ${ }^{8}$ İlerleyen dönemde tarihin bilimselliğinin Jenkins, Kellner ve White gibi tarihçiler tarafından tartışmaya açılması tarihyazımında post-modern anlayışı da beraberinde getirmiştir. Postmodern düşünce tarihyazımı sürecinde o vakte kadar üretilen "tüm bilgiyi” parçalara ayırmış ve şimdiyi anlamanın bir koşulu olarak her bir parçanın ayrı ayrı ele alınması gerektiğini öne sürmüştür. Böylece tarihyazım prensipleri, tek bir merkez, tek bir ülke, kurum ya da kişi üzerinden oluşturulan büyük anlatıların ve didaktik aktarımların etkisinden uzaklaşmaya başlamıştır. Bu yaklaşım, tematik olarak tarih kapsamının genişlemesine ve konularının çeşitlenmesine olanak sağlamıştır. Elbette bu projelerden elde edilen somut çıktıların tüm ulus devletler tarafından değerlendirilmesi zaman almıştır. Alanla ilgili gelişmeler Türkiye örneğinde Türk eğitimi sistemine 2000'li yıllardan itibaren girmeye başlamıştır. Kaynağını pozitivist felsefeden alan davranışçı yaklaşım yerine postmodern ilke-

\footnotetext{
${ }^{6}$ İlhan Tekeli, Birlikte Yazılan ve Öğrenilen Bir Tarihe Doğru, İstanbul: Tarih Vakfı, 2007, s.36-41.

${ }^{7}$ Rousseau, tarihin 15 yaş öncesi çocuklar için uygun olmadığını ileri sürmüş ancak ulus devletler Rousseau'yu dinlememiştir.

${ }^{8}$ C. Husbands, A. Kitson, and A. Pendry, Understanding History Teaching, USA: Open University, 2003, s.10.
} 
lere dayalı yapılandırmacı prensipler müfredatlarda yerini almıştır. ${ }^{9}$ Özellikle 1990’lı yıllardan itibaren Anglo-Saxson geleneği kapsamında üretilen ders kitaplarına da bu etki yansımıștır. ${ }^{10}$

Yeni tarih anlayışı adı verilen bu dönemde İngiltere'de geleneksel eğitim yaklaşımlarının yerini öğrencilerin düşüncelerini geliştirmelerine imkân veren buluş yoluyla öğrenme, probleme dayalı öğrenme ve sokratik diyalog gibi yaklaşımlar benimsenmiştir. ${ }^{11}$ Tarih öğretiminde içerik seçiminde siyasi olaylara ağırlık veren kronolojik tarih öğretimi yerine tematik bir öğretim yaklaşımı ile insanların hayatını en derinden etkileyen, geçmişten günümüze önemini hiç kaybetmemiş konular derslerde çoklu bakış açısıyla incelenmeye başlanmıştır. Böylece öğrenci konuyu ezbere alan pasif profil olmaktan çıkarak, belli bir konu hakkında araştırma yapan, belge toplayan ve bunlar üzerine yorum geliştiren aktif öğrenmeye yönelmiştir. Öğretmenin sorumluluk alanı da merkezi bir düşüncenin temsilcisi olmaktan çıkarılarak, öğrencisini tarihsel merakı konusunda yönlendiren bir rehbere dönüştürülmüştür. Öğretmenin rehberliği ve tematik konu seçimlerinde halen problemler olsa da süreç içinde öğretmenlerin ders işleme tercihlerini yeni yaklaşımlarla besleyebildikleri görülmüştür. ${ }^{12}$

$\mathrm{Bu}$ yaklaşımla birlikte bir merkez tarafından hazırlanan ayrıntılı müfredatların yerini esnek olarak ele alınabilecek temalar almıştır. Böylece tarih bilgisinin sınıf ortamında veya müze, anıt, ören yeri gibi sınıf dışı mekanlarda etkinlikler yoluyla öğrencinin zihninde yapılandırılması ve inşası söz konusu olabilmiştir. Bu durum tarih eğitiminde bilginin aktarımından ziyade onun yapılandırılmasını sağlayacak becerileri ön plana çıkarmıştır. ${ }^{13}$ Bu çerçevede 1990'lardan itibaren özellikle Avrupa'da uluslara dayanan bir bakış açısı yerine ulusüstübir tarih eğitimi kurgusuna yönelik çalışmalara başlandığı ve 2000'lerden itibaren tarih eğitiminde ortak tarih ve kültür oluşturulmasına yönelik projeler hayata geçirildiği görülmüştür. ${ }^{14}$

Milenyumla birlikte tarih öğretim programlarında da değişiklikler gündeme gelmiştir. Özellikle son yıllarda tarih öğretim programları Seixas ve Morton tarafından, Kanadalı öğretmenler için geliştirilen tarihsel önem, kanıt, süreklilik ve değişim, neden sonuç, tarihsel bakış açıları ve etik boyutlarından oluşan "Altı Büyük Tarihsel Düşünme Kavramı” nın yer aldığı görülmektedir. ${ }^{15}$ Hollanda'da “tarihsel akıl yürütme teriminin, öğrencilerin tarihi öğrenirken yalnızca geçmiş hakkında bilgi edinmedikleri, aynı zamanda geçmiş ve bugünkü olguları yorumlarken bu

\footnotetext{
9 Ahmet Şimşek ve Fatih Yazıcı, “Türkiye'de Tarih Öğretiminin Dünü, Bugünü”, TYB Dil Edebiyat ve Sosyal Bilimler Dergisi, 3 (2013), s.9-32.

10 İsmail Güven, "Evolution of History Education as an Academic Discipline in Turkey: The Past and the Present”, ResearchGate, (2018), s.1-19.

${ }^{11}$ Kaya Yılmaz, "Postmodernist Tarih Yaklaşımı: Postmodernizmin Tarih Eğitimi İçin Doğurguları” Pamukkale Üniversitesi Eğitim Fakültesi Dergisi, 34/2 (2013), s.197-209.

12 İbrahim Turan, "Thematic vs Chronological History Teaching Debate: A Social Media Research". Journal of Education and Learning, 9/1 (2020), s.205-216.

${ }^{13}$ Fatih Yazıcı ve Ahmet Şimşek, "Tarih Öğretiminde Nesnellik Sorunu”, Tarih Okulu Dergisi, 11 (2012), s.13-32.

14 Sibel Yalı, “Avrupa'da Tarih Eğitimi ve Öğretimine Yönelik Girişimler ve Avrupa Birliği’nin Katkısı”, Fırat Üniversitesi Sosyal Bilimler Dergisi, 26/1 (2016), s.291-306.

${ }^{15}$ Sibel Yalı, çev., "Tarihsel Düşünme Kriterleri: Kanada Ölçme-Değerlendirme Sistemi için Bir Çerçeve", TUHED, 7/1 (2018), s.240-250.
} 
bilgileri kullandıkları gerçeğine de vurgu yaptığını" görülmektedir. ${ }^{16}$

$\mathrm{Bu}$ değişikliklerin odağında 21. yüzyıl becerileri olarak ifade edilen yetkinliklerin yer aldığı söylenebilir. Bu çerçevede uluslararası ve ulusüstü kurumların alana ilişkin yayınladığı raporlara bakılması konuyla ilgili perspektif vermektedir.

\section{UNESCO'nun 21. Yüzyıl Tarih Eğitimi Prensipleri}

UNESCO, kuruluşunu takip eden ilk on yıl içinde tarih eğitimi konusunda yoğun ve kapsamlı çalışmalar yapmıştır. Organizasyonun, 1946 yılındaki ilk genel kurulunda tarih kitaplarının uluslararası düşmanlıklar yaratmakta nasıl kullanıldığının farkında olarak bu alana önem vereceğini ilan etmesi alana ilişkin mihengi taşıdır. ${ }^{17} \mathrm{Bu}$ çalışmaların genel olarak "Uluslararası Anlayış, İşbirliği ve Barış" konularına referans verdiği görülmektedir. Böylece ulusal kimlik anlayışı ve hoşgörü ilkeleri esasına uygun olarak sorumluluk sahibi ve aktif vatandaşlar yetiştirme ve tüm farklılıklara karşı saygı geliştirme konusunda kritik adımların önü açılmıştır. Kuruluşun, 1947'den günümüze uluslararası anlayış ve barış düşüncesini geliştirecek şekilde eğitim ve özellikle de tarih eğitimi alanında önemli çalışmalara imza attığı ve bu alanda projeler yürüttüğü görülmektedir. ${ }^{18}$

\section{Biiyiuk Tarih Projesi}

Big History Project (BHP) ${ }^{19}$ Büyük Patlama'dan günümüze kadar olan tarihi, disiplinlerarası bir biçimde kapsayan pilot okullar, öğretmenler ve eğitimciler için oluşturulmuş ücretsiz ve çevrimiçi bir eğitim platformudur. Proje, lise öğrencileri arasında öğrenme konusunda daha büyük bir kapasite geliştirmeye adanmıştır. 2011 yılında 7 pilot okulda başlatılan çalışma, 2019 yılı itibariyle 1500'ün üzerinde okulda yaygınlaştırılmıştır. Bu okulların büyük bir bölümü Amerika'da bulunmaktadır. Programda yer alan öğrenciler okuma, yazma ve içerik bilgisinde net ve kanıtlanmış kazanımlar göstermektedir. Programın bu iddiasından ötürü son yıllarda İngiltere'deki okulların da bu programı uygulamaya geçtikleri görülmektedir.

Projenin genel hedefleri 21. yüzyıl becerileri olarak tarif edilen yetkinliklerle ilişkilidir. Bu bağlamda öğrencinin;

- Tarihsel, güncel ve gelecekteki olayları artan karmaşıklık, farklı zaman ve mekân ölçekleri içerisinde daha geniş bir anlatının parçası olarak anlamasına yardımci olmak,

- Evren ve evrensel değişim tarihini algılayabilmek üzere birden fazla disiplinin bakış açısını kullanabilmesi,

- Önemli tarihsel ve bilimsel kavram ve gerçeklerin anlamasını sağlamak,

- Varsayım yapabilmek, araştırılabilir sorular oluşturmak, araştırma yapmak, düşünceyi gözden geçirmek ve bilimsel ve tarihsel kanıtlarla iyi desteklenmiş

16 Jannet van Drie \& Carla van Boxtel, Historical Reasoning: Towards a Framework for Analyzing Students' Reasoning About the Past, Educational Psychology Review, 20/2 (2008), s.87-110.

17 İlhan Tekeli, Birlikte Yazılan ve Öğrenilen Bir Tarihe Doğru, İstanbul: Tarih Vakfı, 2007, s.39-55.

${ }^{18}$ Adnan Altun ve Bahri Ata, "UNESCO’nun Tarih Eğitimi Yayınlarına Yönelik Bir Değerlendirme (19472012)”, Adıyaman Üniversitesi Sosyal Bilimler Enstitüsü Dergisi, 14 (2013), s.107-139.

${ }^{19}$ Sibel Yalı, çev., “Tarih Öğretimine Yeni Bir Yaklaşım: Büyük Tarih Projesi”, TUHED, 8/2 (2019). 
bulgular sunmak suretiyle anlamlı bilimsel araştırma ve tarihsel araştırmalara katılımını desteklemek,

- İyi hazırlanmış ve dikkatlice desteklenen yazılı ve sözlü argümanlar oluşturmak için birincil ve ikincil tarihi, bilimsel ve teknik metinleri eleştirel olarak değerlendirmesini teşvik etmek,

- Temel metin ve konuların analizi yoluyla bilimsel iddiaları desteklemek için argümanlar geliştirmek; bireysel ya da paylaşılan yazma, konuşma ve diğer formatlar aracılığıyla geçerli akıl yürütme ve konuyla ilgili ve yeterli kanıtları kullanmasını sağlamak,

- Evrende kendi bulunduğu, içinde yaşadığı ve global toplumun yeri ve insanlığın bir bütün olarak büyük tarihin anlatılarına nasıl uyduğunu ve onu nasıl etkilediğini kavramasını sağlamak,

- Çeşitli disiplinlerden teorileri ve uygulamaları kullanarak, evrenin tarihinin bütünleşik ve disiplinler arası bir anlayışına doğru tarihsel analizini yapabilmesini teşvik etmek üzere bir müfredat geliştirilmiştir.

\section{OECD Tarih Eğitiminde İlerleme Raporu}

21. yüzyılda ihtiyaç duyulan bilgi, beceri, tutum ve değerler hakkında ortak bir anlayış geliştirmek üzere OECD yürütücülügüünde politika yapıcılar, okul liderleri, öğretmen, öğrenci ve alan uzmanları ile birlikte Eğitimin Geleceği ve Becerileri2030 başlıklı bir rapor hazırlanmıştır. Tarih eğitiminde öğrenme ilerleyişini konu eden raporunda ${ }^{20}$ OECD, eğitim sistemlerinin çevre, ekonomi ve toplum problemleri ile ilişkilendirilerek disiplinlerarası temelde ve bütünsel bir bakış açısıyla ele alınmasının gereği üzerinde durmuştur. Bu çerçevede farklı ülkelerdeki tarih programlarında uygulanan farklı tarih program ve kavram sürümlerinin bir karşılaştırılmasına yer verilmiştir. Rapor içeriğinde İngiltere, Malta, Singapur, Avustralya ve Kanada gibi ülkelerin tarih dersleri ile kazanım hedeflerine değinilmiştir.

\section{EUROCLIO Tarihsel Dïşünme Projesi}

Yüksek kaliteli bir tarih eğitimi için Avrupa Tarih Eğitimcileri Birliği (EUROCLIO) tarafından geçen yıl düzenlenen tarihsel düşünme konulu programda, tarih derslerinin kanıt temelli tartışmalar, farklı tarihlerin varlığı, geçmiş ile tarih arasındaki fark ve günümüz koşullarının geçmişi nasıl etkileyebileceği meseleleri ile nasıl ilişkilendirilebileceği üzerinde bir çalışma yapılmıştır. ${ }^{21}$ Bu çalışma neticesinde tarih dersleri kanalı ile öğrencilere,

- tarihsel yorumları geliştirmek için kaynakları kanıt olarak kullanma,

- değişimi ve sürekliliği açıklama ve değerlendirme,

- neden ve sonucu açıllama ve değerlendirme,

- bir zaman ve yer duygusu tanımlama ve geliştirme,

- öğrenim yolculuklarını yapılandırmak için geçmiş konulu araştırmalar geliştirme,

${ }^{20}$ Louise Zarmatı, "Eğitimin ve Becerilerin Geleceği 2030: Müfredat Analizi Tarih Eğitiminde İlerleme” çev., Sibel Yalı, TUHED, 9/1 (2020), s.369.

${ }^{21}$ Sibel Yalı, çev., "Tarihsel Düşünme Kriterleri”. 
- düşüncelerini sorumlu ve doğrulanabilir bir şekilde iletme becerileri kazandırılması gereksinimine vurgu yapılmıştır.

EUROCLIO, öğretmenler için tarihsel düşünme konulu hazırladığg rehberde dijital malzemelerin de kullanımını teşvik ederek yüksek kaliteli bir tarih anlayışına olan ihtiyacı dile getirmektedir. Bu konuda Avrupa Birliği desteği ile EUROCLIO tarafından hazırlanan Europeana ve Historiana projeleri dijital olarak kullanıcılara hizmet vermektedir. Tablo-1'de okul müfredatlarında uygulanan farklı tarih kavramlarının bir karşılaştırmasına yer verilmiştir. ${ }^{22}$

Tablo1. Okul Müfredatlarında Uygulanan Farklı Tarihsel Kavram Sürümlerinin Karşılaştırılması

\begin{tabular}{|c|c|c|c|c|c|}
\hline $\begin{array}{c}\text { Kanada } \\
\text { (Seixas and } \\
\text { Morton) }\end{array}$ & $\begin{array}{c}\text { Kanada } \\
\text { (Lévesque) }\end{array}$ & $\begin{array}{c}\text { Hollanda } \\
\text { (van Drie and van } \\
\text { Boxtel) }\end{array}$ & $\begin{array}{l}\text { İngiltere } \\
\text { Ulusal } \\
\text { Müfredatı }\end{array}$ & $\begin{array}{l}\text { Australya } \\
\text { Müfredatı }\end{array}$ & $\begin{array}{c}\text { Malta } \\
\text { Müfredatı }\end{array}$ \\
\hline Tarihsel düşünme & $\begin{array}{l}\text { Tarihsel } \\
\text { düşünme }\end{array}$ & $\begin{array}{c}\text { Tarihsel } \\
\text { akıl yürütme }\end{array}$ & $\begin{array}{c}\text { Tarihsel } \\
\text { kavramlar }\end{array}$ & $\begin{array}{c}\text { Anlamak için } \\
\text { tarihsel } \\
\text { kavramlar }\end{array}$ & $\begin{array}{c}\text { Tarihsel } \\
\text { kavramlar }\end{array}$ \\
\hline Önem & Önem & & Önem & Önem & \\
\hline Kanit & Kanit & Kaynak kullanımı & Kanit & Kanıt kullanımı & Kaynak kullanımı \\
\hline $\begin{array}{l}\text { Süreklilik ve } \\
\text { değişim }\end{array}$ & $\begin{array}{l}\text { Süreklilik ve } \\
\text { değişim }\end{array}$ & & $\begin{array}{l}\text { Süreklilik ve } \\
\text { değişim }\end{array}$ & $\begin{array}{l}\text { Süreklilik ve } \\
\text { değișim }\end{array}$ & $\begin{array}{l}\text { Süreklilik ve } \\
\text { değişim }\end{array}$ \\
\hline Sebep ve sonuç & $\begin{array}{l}\text { İlerleme ve } \\
\text { gerileme }\end{array}$ & & Sebep ve sonuç & Sebep ve etki & Sebep ve sonuç \\
\hline \multirow[t]{2}{*}{ Perspektifler } & & & Perspektifler & Perspektifler & \\
\hline & Empati & & & Empati & Empati \\
\hline \multicolumn{6}{|l|}{ Etik boyut } \\
\hline & & Yargılama & & Yarışma & \\
\hline & & & Kronoloji & & $\begin{array}{l}\text { Zaman ve } \\
\text { kronoloji }\end{array}$ \\
\hline & & & Terimler & & \\
\hline & & & $\begin{array}{l}\text { Benzerlik ve } \\
\text { farklılık }\end{array}$ & & $\begin{array}{l}\text { Benzerlik ve } \\
\text { farklılık }\end{array}$ \\
\hline & & Soru sorma & & & \\
\hline & & Bağlamsallaştırma & & & \\
\hline & & $\begin{array}{c}\text { Asli kavramları } \\
\text { kullanma* }\end{array}$ & & & \\
\hline & & $\begin{array}{l}\text { Meta kavramları } \\
\text { kullanma* }\end{array}$ & & & \\
\hline
\end{tabular}

\section{Dïnya Ekonomik Forumu Geleceğin Okulları Raporu}

WEF tarafından geçen yıl yayınlanan Geleceğin Okulları: Dördüncü Sanayi Devrimi için Yeni Eğitim Modellerini Tanımlama başlıklı raporda, eğitim sistemlerindeki sorunlara dikkat çekilmiştir. Bu rapor, 4. Endüstri Devrimi'nde yeni eğitim modellerine yönelik kapsamlı bir bakış açısı sunmaktadır. Bu özellikler, İngilizce diline karşılık gelecek 21 adet kelime öbeğinin oluşturduğu 3Rx7C'nin çarpımı şeklinde formülleştirilen okuma, yazma, aritmetik ile merak, yaratıcılık, eleştirel düşünme, işbirliği, iletişim, kültürlerarası anlayış ve iletişim teknolojileri kullanım becerilerine işaret etmektedir. WEF çerçevesinde bu beceriler,

- küresel vatandaşlık

- yenilikçilik ve yaratıcılık

\footnotetext{
${ }^{22}$ Louise Zarmatı, çev., "Eğitimin ve Becerilerin Geleceği 2030”, s. 369.
} 
- teknoloji kullanım

- empati, duygusal zeka, müzakere gibi kişiler arasılık

- kişiselleştirilmiş ve öğrenme hızı ile düzeyine bağlı

- erişilebilir ve kapsayıcı

- işbirliğine dayalı

- hayat boyu öğrenme ve öğrenme motivasyonu

içerikli beceriler üzerine inşa edilmiştir. Bu çerçevede raporda örnek olarak verilen okulların tarih ve sosyal bilgiler ders programları ele alındığında bu programların da 21. yüzyıl becerilerini kapsadığı görülmektedir. Bu bağlamda dersler sırasinda öğrencilerden;

- öğrenme sürecinde gerçek hayat problemini belirleme ve tanımlama,

- sorunu araştırma ve ilgili araç ve bilgileri bulma,

- bilgiyi eleştirel olarak analiz ve test etme,

- problem üzerinde çalışma ve çeşitli kaynaklardan faydalanmak için toplulukta küçük eko-işbirliği sistemleri kurma,

- olası çözümler tasarlama ve çözümleri daha geniş bir topluluk kitlesine sunma,

faaliyetlerini gerçekleştirmeleri talep edilmektedir. Örneğin geleceğin yeşil liderlerini yetiştirmeyi hedefleyen Yeşil Okul projesinin müfredatı küresel vatandaşlık kategorisi altında düşün-harekete geç ve etkile yaklaşımlarını temel alarak oluşturulmuştur. Müfredatta yaratıcı, eleştirel ve sistemler üzerine düşünmeyi zorunlu kılan ve buradan çıkan problemler odaklı birlikte ve iletişim halinde aksiyon alma sürecini başlatan bir program önerisi sunulmaktadır. Bu yaklaşımın yansımaları da bilimsel kriterler çerçevesinde analiz edilmektedir. Öğrencilerin öğrenme merakı, ilgisi ve hızı çerçevesinde öğrenciye dönük araştırma projeleri ile öğrencinin akademik başarısı desteklenmektedir.

\section{Avrupa Konseyi Kaliteli Tarih Eğitimi Prensipleri}

Avrupa Konseyi (AK) tarafından tarih eğitimi ve paydaşları için hazırlanan rehberde tarih eğitiminde "kalite" kavramına vurgu yapılmaktadır. ${ }^{23} \mathrm{Bu}$ rehberle, tarih eğitiminin nasıl yapılması ve yapılmaması gerektiği konusundaki kriterler için AK tarafından bir çerçeve geliştirilmiş ve bu kriterlerin denetimi konusunda AK’nın bazı önemli belgelerinde belirtildiği üzere, AK’nın tarih öğretimi vizyonunu içeren ilkeler sunulmuştur. Bu ilkeler sırasıyla;

- Kültürel farklılıkları kabul eden esnek müfredat ve etkileşimli pedagoji geliştirme

- Demokrasinin karmaşık tarihinin öğrenimi ve öğretimi

- Sıradan bireylerin ve grup faaliyetlerinin toplum tarihini nasıl şekillendirdiğini yansitmak

- Farklı kültürel, dini ve etnik kökene sahip kişilerin toplumlarda yerleşik ol-

${ }^{23}$ Sibel Yalı, çev., “21. Yüzyılda Kaliteli Tarih Eğitimi: Prensipler ve Kılavuzlar”, TUHED, 8/1 (2019). 
duğunu kabul etme

- Hem "ötekinin" hem de kendimizin çoklu kimliklerini değerleme

- Tarihsel kaynakları değerlendirmek ve manipülatif propaganda ile mücadele etmek için araçlar sağlama

- Hassas veya tartışmalı olabilecek konuları ele alma

- Tarih öğretimi ve öğreniminin bilişsel, duygusal ve etik boyutlarını dengeleme başlıklarını taşımaktadır.

$\mathrm{Bu}$ başlıklar genel olarak geçmişin bilgisi konusunda, insan davranışının karmaşıklığına ve çeşitliliğine referans vermekte; farklı, hatta çelişkili anlatıları sorgulama yeteneğini teşvik etmekte; argümanların geniş kapsamlı kanıtların anlaşılmasıyla ele alınmasını zorunlu kılmaktadır. Dolayısıyla okullardaki tarih eğitiminin AK tarafından referans verilen bu katkılarından ancak neyin, nasıl öğretildiği ve mevcut kaynakların kalitesinin buna izin vermesi durumunda söz edilebilmektedir.

Rehberde Çeşitlilik ve demokrasi için eğitim: Çağdaş Avrupa'da tarih öğretimi isimli hükümetler arası proje çerçevesinde 2016-2017 döneminde düzenlenen dört bölgesel seminer çerçevesinde elde edilen veriler dikkate alınmıştır. Bunlar, çeşitli, kapsayıcı ve demokratik toplumlar oluşturmak; hassas ve tartışmalı konularla ilgilenmek ve dijital çağda eleştirel tarihsel düşünceyi geliştirmek üzere üç ana temaya ilişkindir. Bu temalar okullarda öğretilen tarihin doğasına, niteliği ve etkisine ilgi duyan öğrenci, veli ve halkın geneli dâhil herkesin tarih bilgisinin analitik düzeyde, problem çözme ve diğer üst düzey bilişsel, kişilerarası ve sosyal becerilerin yanı sıra okuryazarlık ve sayısal derslerde temel becerilerin kazanımını hedeflemektedir.

\section{"21. Yüzyıl Becerileri" Yaklaşımı Tarih Eğitimi Pratikleri}

Formel tarih eğitimi okullaşmaya paralel olarak yüzlerce yıllık bir tarihyazımı geleneğinden çok sonra ortaya çıkmıştır. Eğitim pratikleri bazen bu gelenekten etkilenerek bazen de bu geleneği etkileyerek varlığını sürdürmüştür. Bir diğer deyişle tarih eğitimi, ulus-devlet ve kapitalist ekonomi ile aynı dönemde ortaya çıkmış ve konjonktürün ihtiyaçlarına göre formatlanmıştır. Tarih eğitimindeki bu formatlara hakim olan yaklaşımlar, genel itibariyle 18.yüzyılın son çeyreğinde başlamış ve 20.yüzyılın son çeyreğine kadar pozitivist ve romantik çerçevede şekil almıştır. 1970'lerden itibaren tarih eğitiminde postmodernizm etkisi de görülmeye başlanmıştır. Tarihyazımında meydana gelen tematik çeşitlenme ile pedagojik yaklaşımlardaki gelişmeler tarih eğitimi içeriğinde sınırlı da olsa kendine yer bulmuştur. Tüm gelişmelere rağmen geçtiğimiz iki asırlık süre çerçevesinde tarih eğitimi resmi tarihyazımı etkisinden kendini kurtaramamıştır.

Resmi tarihçilik önce imparatorluklarda sonra da ulus devletlerde resmi belgelere dayanan bir anlatı kurma çabası olarak üniversitelerde kürsüleşmiştir. Resmi tarihyazım ile amaçlanan, birey ile ulus arasında milli, dini ve sembolik bağlar kurabilmektir. Bu bağların kurulabilmesi, "resmî bilgi" adı verilen resmî müfredat ve ders kitapları kanalı ile mümkün olabilmiştir. Bu yol ile amaçlanan ulusal bilinci kuvvetlendirmek, kendini gerektiğinde vatanı için kurban etmek, vatanse- 
verliği güçlendirmek ve ulusunun tarihsel devamlılığını sürdürmektir. Müfredatta "resmi bilgi"ye yer verilmesi konuyu tartışmalı hale getirmektedir. Bu tarz bilgi bir otorite veya geleneğin veyahut bazı kişiler ile grupların meşru bilgi anlayışının bir parçası şeklindedir. ${ }^{24}$ Dolayısıyla, resmi bilgi kanalı ile müfredat ve ders kitaplarına tek sesli ifadeler, tarihselci ve özcü anlatılar ile düşmanca tavırlar siyasi bir arka plan ile yansitılmaktadır.

Milenyumla birlikte özellikle refah düzeyi yüksek ülkelerde tarih eğitimi kazanımlarının resmi tarih odağından uzaklaştığ 1 görülmektedir. Ders içerikleri, 21. yüzyıl becerileri perspektifi ile desteklenmekte, kazanımlar eleştirel düşünme ve problem çözme becerileri ekseninde geliştirilmektedir. Tarihsel olaylara yaklaşımda ise çok perspektifliliğin benimsendiği ve kültürel mirasın ortak yönlerinin takdir edilmesi gibi amaçlar ile ilişkilendirildiği görülmektedir. Bu çerçevede Kanada, Avustralya, İngiltere ve Amerika'daki tarih ve sosyal bilgiler dersleri için hazırlanan güncel müfredatlar konu ekseninde perspektif vermektedir.

\section{ABD Örneği}

Ülkede eğitim öncelikle eyalet ve yerel yönetimlerin sorumluluğundadır. Her eyaletin kendi eğitim departmanı ve finans, okul personelinin işe alınması, öğrenci katılımı ve müfredatı ile ilgili yasaları vardır. Devletler ayrıca zorunlu eğitim yıllarının sayısını da belirler - bazı eyaletlerde eğitim yalnızca 16 yaşına kadar zorunludur. Ülke nüfusunun farklı bileșenlerinin olması nedeniyle 2015 yılında ABD müfredatları ABD'deki her çocuğa "1rk, gelir, geçmiş, posta kodu veya nerede yaşadıklarına bakılmaksızın” aynı eğitim standardını sunmayı taahhüt eden "Her Öğrenci Başarılı Yasası" üzere yapılandırılmıştır. Bu yapılanma çerçevesinde tarih eğitiminin nitelik ve kriterleri de tarihsel düşünme becerilerinin geliştirilmesi bağlamında ele alınmıştır. ${ }^{25}$ Tabloda bu yeterliliklerin bir çerçevesi görülmektedir.

Tarih eğitimi alanında standartlar geliştirilmesi konusundaki proje, Ulusal Tarih Standartları Konseyi'nin rehberliğinde Kaliforniya Üniversitesi, Ulusal Tarih Merkezi tarafından 1990’lı yıllarda yönetilmiştir. Ulusal Tarih Standartları'nın bu çalışması tarih eğitiminde "Tarihsel Düşünme", "ABD Tarihi” ve "Dünya Tarihi" olmak üzere üç alanda standart geliştirmiştir. Eyaletlerin bu standartlara uyma zorunluluğu bulunmamakla birlikte genel prensipler olarak kabul görmüştür.

Tablo 2. ABD Tarih Dersleri ile Öğrencilerde Geliştirilmesi Planlanan Beceriler

\begin{tabular}{|l|l|}
\hline Kronolojik Düşünme & Neden Sonuç, Değişim Olgusu, Dönemlendirme \\
\hline Kıyaslama ve Metin Analizi & Kiyaslama, Metin Analizi \\
\hline Tarihsel Kanıt ve Tartışma Yürütme & Tartı̧malı Konular, Tarihsel Kanıt Sunumu \\
\hline Tarihsel Yorum ve Sentez Geliştirme & Yorumlama, Sentez \\
\hline
\end{tabular}

\section{Kanada Örneği}

Kanada'daki eğitim, eyaletlere ve bölgelere göre yapılandırılmıştır. Bu çerçevede

${ }^{24}$ Michael W. Apple, M. Official Knowledge: Democratic Education in a Conservative Age. NY: Routledge, 1993, s.9-15.

25 "UCLA History Standarts". 
incelenen British Columbia eyaletinde tarih müfredatının ${ }^{26}$, Sosyal Bilgiler öğrenme alanına dahil ve hiyerarşik olarak düzenlenmiş olduğu görülmüştür. Program, tarihsel düşünme prensiplerinin temel yetkinlikleri baz alınarak oluşturulmuştur.

Bu tabloda Kanada British Columbia Eyaleti sosyal bilgiler dersleri sinıflara göre kazanım listesi görülmektedir. Bu listeye göre sosyal bilgiler müfredatında, öğrencilerin öğrenme döneminin (sınıfının) sonunda neler yapabileceğini tarif etmek için tanımla, açıkla ve değerlendir gibi aktif fiiller kullanılmaktadır. Araştırma sürecinde öğrencilerin, altı ana düşünme kavramı olan önem; kanıt; süreklilik ve değişim; neden ve sonuç; perspektif ve etik yargı kavramları aracılığıyla düşünme becerileri geliştirilmektedir. ${ }^{27}$ Müfredatın amacı, öğrencilerin "sorunları çözmek, karar vermek ve fikirlerini etkili bir şekilde iletmek” için kullanacakları altı düşünme kavramının "dünyanın dört bir yanındaki kaynaklardan neredeyse her konuda bilgi” ye uygulanabileceği olarak görülmektedir. Bu yaklaşım, OECD'nin yirmi birinci yüzyıl öğrencilerinin mezkur becerileri öğrenmesi gerektiği tavsiyesiyle örtüştüğü görülmektedir.

Tablo 3. Kanada British Colombia Eyaleti Sosyal Bilgiler Dersleri Sinıflara Göre Kazanimları

\begin{tabular}{|c|c|c|c|}
\hline & 7 & 8 & 9 \\
\hline Önem & $\begin{array}{l}\text { Belirli zamanlarda ve } \\
\text { yerlerde insanların, } \\
\text { yerlerin, olayların veya } \\
\text { gelișmelerin önemini } \\
\text { değerlendirin. } \\
\text { Tanıklıkların, anlatıların, } \\
\text { haritaların veya } \\
\text { metinlerin içerik } \\
\text { olușturucularının } \\
\text { belirledikleri önemi } \\
\text { tespit edin. }\end{array}$ & $\begin{array}{l}\text { Belirli zamanlarda ve } \\
\text { yerlerde insanların, } \\
\text { yerlerin, olayların veya } \\
\text { gelișmelerin önemini } \\
\text { değerlendirin. } \\
\text { Tanıklıkların, } \\
\text { anlatıların, haritaların } \\
\text { veya metinlerin içerik } \\
\text { olușturucularının } \\
\text { belirledikleri önemi } \\
\text { tespit edin. }\end{array}$ & $\begin{array}{l}\text { Belirli zamanlarda ve } \\
\text { yerlerde insanların, } \\
\text { yerlerin, olayların veya } \\
\text { gelișmelerin önemini } \\
\text { değerlendirin ve belirli } \\
\text { zamanlarda / yerlerde } \\
\text { ve gruptan gruba } \\
\text { tarihsel önem } \\
\text { hakkında değişen } \\
\text { perspektifleri } \\
\text { karşılaştırın. }\end{array}$ \\
\hline Kanıt & $\begin{array}{l}\text { Birden fazla kaynağın } \\
\text { güvenilirliğini ve } \\
\text { sonuçları doğrulamak } \\
\text { için kullanılan kanıtların } \\
\text { yeterliliğini } \\
\text { değerlendirin. }\end{array}$ & $\begin{array}{l}\text { Birden fazla kaynağın } \\
\text { güvenilirliğini ve } \\
\text { sonuçları doğrulamak } \\
\text { için kullanılan kanıtların } \\
\text { yeterliliğini } \\
\text { değerlendirin. }\end{array}$ & $\begin{array}{l}\text { Çatışma noktalarını, } \\
\text { kaynakların } \\
\text { güvenilirliğini ve } \\
\text { kanıtların yeterliliğini } \\
\text { araștırdıktan sonra, } \\
\text { farklı tarihsel } \\
\text { görüşlerin } \\
\text { gerekçelerini } \\
\text { değerlendirin. }\end{array}$ \\
\hline $\begin{array}{l}\text { Süreklilik } \\
\text { \& Değişim }\end{array}$ & $\begin{array}{l}\text { İlerleme ve düşüş } \\
\text { dönemleri de dahil } \\
\text { olmak üzere tarihte farklı } \\
\text { zaman dönemlerini } \\
\text { tanımlayın ve değișim } \\
\text { dönemlerini işaretleyen } \\
\text { önemli dönüm }\end{array}$ & $\begin{array}{l}\text { İlerleme ve düşüss } \\
\text { dönemleri de dahil } \\
\text { olmak üzere tarihte } \\
\text { farklı zaman } \\
\text { dönemlerini tanımlayın } \\
\text { ve değişim dönemlerini } \\
\text { işaretleyen önemli }\end{array}$ & $\begin{array}{l}\text { Farklı grupların aynı } \\
\text { zaman aralığındaki } \\
\text { sürekliliklerini ve } \\
\text { değişikliklerini } \\
\text { karşılaştırın. }\end{array}$ \\
\hline
\end{tabular}

26 "The Ontario Curriculum Social Studies, History and Geography".

${ }^{27}$ Peter Seixas and Tom Mortan, The Big Six Historical Thinking Concepts, Nelson College Indigenous, 2013. 


\begin{tabular}{|c|c|c|c|}
\hline & noktalarını belirleyin. & $\begin{array}{l}\text { dönüm noktalarını } \\
\text { belirleyin. }\end{array}$ & \\
\hline $\begin{array}{l}\text { Neden \& } \\
\text { Sonuç }\end{array}$ & $\begin{array}{l}\text { Belirli kararları, } \\
\text { eylemleri veya olayları en } \\
\text { çok etkileyen nedenleri } \\
\text { belirleyin ve kısa ve uzun } \\
\text { vadeli sonuçlarını } \\
\text { değerlendirin. }\end{array}$ & $\begin{array}{l}\text { Belirli kararları, } \\
\text { eylemleri veya olayları } \\
\text { en çok etkileyen } \\
\text { nedenleri belirleyin ve } \\
\text { kısa ve uzun vadeli } \\
\text { sonuçlarını } \\
\text { değerlendirin. }\end{array}$ & $\begin{array}{l}\text { Geçerli koșulların ve } \\
\text { bireylerin / grupların } \\
\text { eylemlerinin olayları, } \\
\text { kararları veya } \\
\text { gelişmeleri nasıl } \\
\text { etkilediğini } \\
\text { değerlendirin. }\end{array}$ \\
\hline Perspektif & $\begin{array}{l}\text { Geçmiş ya da şimdiki } \\
\text { insanlar, yerler, meseleler } \\
\text { ya da olaylar hakkında } \\
\text { farklı bakıș açılarını } \\
\text { açıklayın ve farklı zaman } \\
\text { ve yerlerde insan kültürü } \\
\text { ve toplumlarının } \\
\text { değerlerini, dünya } \\
\text { görüşlerini ve inançlarını } \\
\text { karşılaştırın. }\end{array}$ & $\begin{array}{l}\text { Geçmiş ya da şimdiki } \\
\text { insanlar, yerler, } \\
\text { meseleler ya da olaylar } \\
\text { hakkında farklı bakıș } \\
\text { açılarını açıklayın ve } \\
\text { farklı zaman ve yerlerde } \\
\text { insan kültürü ve } \\
\text { toplumlarının } \\
\text { değerlerini, dünya } \\
\text { görüșlerini ve } \\
\text { inaçlarını karşılaștırın. }\end{array}$ & $\begin{array}{l}\text { Geçerli normları, } \\
\text { değerleri, dünya } \\
\text { görüşlerini ve inançları } \\
\text { göz önünde } \\
\text { bulundurarak geçmiş } \\
\text { veya mevcut insanlar, } \\
\text { yerler, konular veya } \\
\text { olaylar hakkında farklı } \\
\text { bakıș açılarını açıklayın } \\
\text { / anlamlarını çıkarın. }\end{array}$ \\
\hline $\begin{array}{l}\text { Etik } \\
\text { Düşünce }\end{array}$ & $\begin{array}{l}\text { Geçmiş olaylar, kararlar } \\
\text { veya eylemler hakkında } \\
\text { etik yargılarda bulunun } \\
\text { ve geçmișten doğrudan } \\
\text { ders çıkarmanın } \\
\text { sinırlarını değerlendirin. }\end{array}$ & $\begin{array}{l}\text { Geçmiș olaylar, kararlar } \\
\text { veya eylemler hakkında } \\
\text { etik yargılarda bulunun } \\
\text { ve geçmișten doğrudan } \\
\text { ders çıkarmanın } \\
\text { sınırlarını değerlendirin. }\end{array}$ & $\begin{array}{l}\text { Çeșitli kaynaklardaki } \\
\text { örtülü ve açık etik } \\
\text { yargıları fark edin. } \\
\text { Geçmișteki ve } \\
\text { günümüzdeki eylemler } \\
\text { hakkında mantıklı etik } \\
\text { yargılarda bulunun, } \\
\text { hatırlamak ve cevap } \\
\text { vermek için uygun } \\
\text { yolları belirleyin. }\end{array}$ \\
\hline
\end{tabular}

\section{Avustralya Örneği}

Avustralya eğitim müfredatı, Avustralya eğitim sisteminin kalitesini, eşitliğini ve şeffaflığını iyileştirme ilkelerine dayanmaktadır. Genel olarak eğitim çerçevesini İngilizce; matematik; bilim; insan ve toplum bilimleri; sanat; teknoloji; ikinci dil öğretimi ile sağlık ve beden eğitimi alanları oluşturur. Lise alanı son iki yılında öğrencilere İngilizce, matematik, fen, tarih ve coğrafya alanlarından seçebilmeleri üzere dersler sunulur. Bu çerçevede ana amaç anlama derinliği, bilginin kapsamı ve becerinin karmaşıklığ 1 dahil öğrenmenin kalitesi odaklıdır. Bu bağlamda Avustralya'daki eğitim, Kanada örneğinde olduğu gibi eyaletlere ve bölgelere göre yapılandırılmıştır. Bu yapılandırmada da 21. yüzyıl yetkinliklerinin temel alındığ 1 görülmektedir.

$\mathrm{Bu}$ çerçevede incelenen müfredatta ${ }^{28}$, Sosyal Bilgiler öğrenme alanının, tarihsel düşünme prensiplerinin temel yetkinlikleri temel alınarak oluşturulduğu görülmüştür. Tabloda sosyal bilgiler derslerinin yaş ve sınıflara göre kazanımları görülmektedir.

Tablo 4. Avustralya Sosyal Bilgiler Dersleri Sınıflara Göre Kazanımları

\begin{tabular}{l|l} 
7. sınıfın sonunda (13 yaşında) bir & 8. sınıfın sonunda (14 yaşında) bir öğrencinin \\
\hline
\end{tabular}

28 "Australian Curriculum: Humanities and Social Sciences learning area Online". 


\begin{tabular}{|c|c|}
\hline öğrencinin yapabilecekleri: & yapabilecekleri: \\
\hline $\begin{array}{l}\text { zaman içindeki değişim ve süreklilik için } \\
\text { nedenler önermek }\end{array}$ & $\begin{array}{l}\text { zaman içindeki değișim ve süreklilik } \\
\text { kalıplarını tanımak ve açıklamak }\end{array}$ \\
\hline $\begin{array}{l}\text { değişimin toplumlar, bireyler ve gruplar } \\
\text { üzerindeki etkilerini tanımlamak }\end{array}$ & $\begin{array}{l}\text { olay ve gelişmelerin nedenlerini ve etkilerini } \\
\text { açklamak }\end{array}$ \\
\hline $\begin{array}{l}\text { olayları ve gelișmeleri o sırada yaşayan farklı } \\
\text { insanların bakış açlarından tanımlamak }\end{array}$ & $\begin{array}{l}\text { o zamandaki insanların güdülerini ve } \\
\text { eylemlerini tanımlamak }\end{array}$ \\
\hline $\begin{array}{l}\text { grupların rolünü ve belirli bireylerin } \\
\text { toplumdaki önemini açılamak }\end{array}$ & $\begin{array}{l}\text { Bireylerin ve grupların önemini ve } \\
\text { toplumlarının inançlarından ve değerlerinden } \\
\text { nasıl etkilendiğini açıklamak }\end{array}$ \\
\hline $\begin{array}{l}\text { farklı ssekillerde yorumlanmış geçmiş olay ve } \\
\text { gelişmeleri tanımlamak }\end{array}$ & geçmişin farklı yorumlarını anlatmak \\
\hline $\begin{array}{l}\text { zamanı temsil etmek ve ölçmek için } \\
\text { tarihlendirme kurallarını kullanarak olayları } \\
\text { ve gelișmeleri kronolojik bir çerçevede } \\
\text { sıralamak }\end{array}$ & $\begin{array}{l}\text { olayları ve gelişmeleri zaman aralıklarına göre } \\
\text { kronolojik bir çerçeve içinde sıralamak }\end{array}$ \\
\hline $\begin{array}{l}\text { araștırma yaparken tarihsel bir çalıșmayı } \\
\text { çerçevelemek için sorular geliștirmek }\end{array}$ & $\begin{array}{l}\text { arasstırma yaparken tarihsel bir çalışmayı } \\
\text { çerçevelemek için sorular geliștirmek }\end{array}$ \\
\hline $\begin{array}{l}\text { bir dizi kaynağı tanımlamayarak / seçerek } \\
\text { sorularını cevaplamak üzere gerekli bilgileri } \\
\text { bulmak, karşılaștırmak ve kullanmak }\end{array}$ & $\begin{array}{l}\text { birincil ve ikincil kaynaklardan gelen bilgileri } \\
\text { analiz etmek, seçmek ve düzenlemek, soruları } \\
\text { cevaplamak üzere kanıt olarak kullanmak }\end{array}$ \\
\hline $\begin{array}{l}\text { farklı bakıs açılarını açıklamak için } \\
\text { kaynakları incelemek }\end{array}$ & $\begin{array}{l}\text { Kaynaklardaki farklı bakış açılarını } \\
\text { tanımlamak ve açıklamak }\end{array}$ \\
\hline $\begin{array}{l}\text { kaynakları yorumlarken kökenlerini ve } \\
\text { amaçlarını tespit etmek }\end{array}$ & $\begin{array}{l}\text { kaynakları yorumlarken kökenlerini ve } \\
\text { amaçlarını belirlemek, olgu ve fikir arasında } \\
\text { ayrım yapmak }\end{array}$ \\
\hline $\begin{array}{l}\text { metin gelisstirirken ve bulgularını organize } \\
\text { edip sunarken tarihsel terim ve kavramları } \\
\text { kullanmak, ilgili kaynakları dahil etmek }\end{array}$ & $\begin{array}{l}\text { bulgularını organize ederek sunarken tarihsel } \\
\text { terim ve kavramları, kaynaklarda belirlenen } \\
\text { kanıtları kullanmak ve bilgi kaynaklarını } \\
\text { tanımak }\end{array}$ \\
\hline
\end{tabular}

\section{Ingiltere Örneği}

İngiltere Ulusal Müfredatı, öğrencilere eğitimli vatandaşlar olmak için ihtiyaç duydukları temel bilgilere bir giriş sağlamayı amaçlar. Bu çerçevede öğrencilerin, ilgili dersler kanalıyla çeşitli kuram ve tartışmalar ile birlikte insanlık tarihindeki problem ve çözümler ile karşılaşmaları sağlanır. Bu karşılaşmalar, öğrencileri gelecek yaşama hazırlarken aynı zamanda onların ruhsal, ahlaki, kültürel, zihinsel ve fiziksel gelişimini destekleyen, dengeli ve geniş tabanlı bir müfredat sunmayı da amaçlar. Bu amaçlar doğrultusunda üç temel aşamada yapılandırılan tarih ve sosyal bilgiler müfredatında ${ }^{29}$ da tarihsel düşünme becerilerinin ön plana çıktığg 1 görülmektedir. Tabloda İngiltere'deki öğrencilerin yaşları bağlamında geliştirebileceği tarihsel düşünme temelli kazanımlar görülmektedir.

\section{Tablo 5. Ingiltere Sosyal Bilgiler Dersleri Sınıflara Göre Kazanımlar}

\begin{tabular}{|c|c|c|}
\hline $\begin{array}{c}\text { Temel Așama } 1 \\
5-7 \text { Yaş }\end{array}$ & $\begin{array}{c}\text { Temel Așama } 2 \\
7-11 \text { Yaş }\end{array}$ & $\begin{array}{c}\text { Temel Aşama } 3 \\
11-14 \text { Yaş }\end{array}$ \\
\hline $\begin{array}{l}\text { Zamanın geçmesi ile ilgili } \\
\text { ortak kelimeler ve ifadeler } \\
\text { kullanarak geçmiș } \\
\text { hakkında bir farkındalık }\end{array}$ & $\begin{array}{l}\text { Çalıștıkları dönemler içinde } \\
\text { ve arasında net anlatılar } \\
\text { kurarak İngiliz, yerel ve } \\
\text { dünya tarihi hakkında }\end{array}$ & $\begin{array}{l}\text { İngiliz, yerel ve dünya } \\
\text { tarihinin kronolojik olarak } \\
\text { güvenli bilgi ve anlayıșını } \\
\text { genișletir / derinleștirir, }\end{array}$ \\
\hline
\end{tabular}

\footnotetext{
29 "National Curriculum in England: History programmes of study Online".
} 


\begin{tabular}{|c|c|c|}
\hline geliştirir. & $\begin{array}{l}\text { kronolojik olarak güvenli bir } \\
\text { bilgi ve anlayış geliştirmeye } \\
\text { devam eder. }\end{array}$ & $\begin{array}{l}\text { böylece daha geniş öğrenme } \\
\text { için iyi bilgilendirilmiş bir } \\
\text { bağlam sağlar. }\end{array}$ \\
\hline $\begin{array}{l}\text { Çalıștıkları kişi ve olayların } \\
\text { kronolojik bir çerçevede } \\
\text { nereye uyduğunu bilir ve } \\
\text { farklı dönemlerde yaşam } \\
\text { biçimleri arasında } \\
\text { benzerlikleri ve farklılıkları } \\
\text { belirler. }\end{array}$ & $\begin{array}{l}\text { Zaman içindeki bağlantıları, } \\
\text { zıtlıkları ve eğilimleri not } \\
\text { eder ve tarihsel terimlerin } \\
\text { uygun kullanımını geliştirir. }\end{array}$ & $\begin{array}{l}\text { Önemli olayları tanımlar, } \\
\text { bağlantı kurar, kontrastları } \\
\text { çizer ve uzun dönemler } \\
\text { boyunca trendleri analiz } \\
\text { eder. }\end{array}$ \\
\hline $\begin{array}{l}\text { Geniș bir günlük tarihsel } \\
\text { terim dağarcı̆̆ı kullanır. }\end{array}$ & $\begin{array}{l}\text { Değissim, neden, benzerlik / } \\
\text { farklılık ve önem hakkında } \\
\text { tarihsel olarak geçerli } \\
\text { soruları düzenli olarak ele } \\
\text { alır, ve bazen bunları } \\
\text { olușturur. }\end{array}$ & $\begin{array}{l}\text { Tarihsel terim ve kavramları } \\
\text { gittikçe daha sofistike bir } \\
\text { şekilde kullanır. }\end{array}$ \\
\hline $\begin{array}{l}\text { Olayların temel } \\
\text { özelliklerini bildiklerini ve } \\
\text { anladıklarını göstermek } \\
\text { için öykülerin ve diğer } \\
\text { kaynakların bölümlerini } \\
\text { seçerek / kullanarak sorular } \\
\text { sorar ve cevaplar. }\end{array}$ & $\begin{array}{l}\text { Gerekli tarihsel bilgilerin } \\
\text { özenle seçilmesini ve } \\
\text { düzenlenmesini içeren } \\
\text { bilinçli yanıtlar oluşturur. }\end{array}$ & $\begin{array}{l}\text { Bazılarını kendilerinin } \\
\text { oluşturdukları tarihsel } \\
\text { olarak geçerli soruları takip } \\
\text { eder ve bunlara alakall, } \\
\text { yapılandırılmıs ve kantssal } \\
\text { olarak desteklenen yanttlar } \\
\text { oluştururlar. }\end{array}$ \\
\hline $\begin{array}{l}\text { Geçmişi öğrendiğimiz bazı } \\
\text { yolları anlar ve temsil } \\
\text { edildiği farklı yolları } \\
\text { tanımlar. }\end{array}$ & $\begin{array}{l}\text { Geçmiş hakkındaki } \\
\text { bilgimizin bir dizi } \\
\text { kaynaktan nasıl inşa edilmişs } \\
\text { olduğunu anlar. }\end{array}$ & $\begin{array}{l}\text { Tarihsel iddialarda } \\
\text { bulunmak için farklı } \\
\text { tarihsel kaynak türlerinin } \\
\text { nasıl titizlikle kullanıldığını } \\
\text { anlar ve geçmișin } z ı t \\
\text { argümanlarının ve } \\
\text { yorumlarının nasıl ve neden } \\
\text { inșa edildiğini ayırt eder. }\end{array}$ \\
\hline
\end{tabular}

\section{Türkiye Örneği}

Eğitim ve öğretimin daha kaliteli bir şekilde sunulması amacıyla Türkiye'de de yurtdışındaki eğitim politikalarındaki gelişmelere paralel olarak bazı güncellemeler yapılmıştır. Bu bağlamda 2005 yılında ilk ve ortaöğretimde program güncellenmesi yapılmış, 2007-2012 yılları arasında tarih öğretim programlarında da yapılandırmacı yaklaşım ekseninde revizeler yapılmıştır. Bu çalışmalar her ne kadar sınav sistemlerinin ve mevcut ideolojilerin yoğun etkisinden kendisini arındıramasa da 2017 yılında taslak şeklini almıştır. Bir sonraki yıl programlara nihai şekil verilmiştir.

MEB Ortaöğretim Tarih Eğitimi Taslak Programı’nda tarih eğitiminin en önemli görevi olarak tarihsel düşünme yaklaşımı ekseninde öğrencilerin kanıt değerlendirme, eleştirel düşünme ve problem çözme gibi becerilerin kazandırılmasına yönelik bir vurgu olduğu görülmektedir. Ancak bu programın pratikteki karşılığının farklı olduğunu söylemek mümkündür. Zira programın içeriğinin "Türk Tarihi'nin akışı içinde ana hatlarıyla bazı önemli bulunanları dünya tarihi perspektifinden (mümkün olduğunca daha çok karşılaştırmaya dayalı), daha derinlikli öğrenmeye, bunu yaparken de tarihsel düşünme becerileri ve çağdaş değerleri de kazandırmaya yönelik bir program" yerine "her şeyi öğretmek iddiası" ile şe- 


\section{killendiği söylenebilir. ${ }^{30}$}

Müfredatlar iş dünyasının beklentileri, alanyazın eleştirileri ve mevcut politikalar ekseninde geçtiğimiz yıl revize edilmiştir. Buna göre ders sayıları azaltılmış, deneyime yönelik programlar geliştirilmiş, programlar atölye ve laboratuvarlarla desteklenmiş ve derslerde disiplinlerüstü yaklaşım benimsenmiştir. İlaveten alan dersleri için proje ve uygulama çalışmaları teşvik edilmiştir. Bilginin değere dönüştürülmeye çalışıldığ 1 bu yeni sisteme Hayal, Etkinlik ve Yaşam (HEY) adı verilmiştir. ${ }^{31}$ Bakanlık tarafından yapılan açıklamada ortaöğretim alanında yapılan bu uygulamanın gerekçesi olarak şu nedenler paylaşılmıştır:

- gençleri geleceğe hazırlamanın önemi,

- eğitimin ekonominin taşıyıcı unsuru olması,

- sinav yerine temel becerilerin getirilmesi zorunluluğu,

- bilginin değer yaratan bir unsur haline dönüştürülebilmesi,

- öğrencilerin derslerde kendi merak ve seçimleri doğrultusunda derinleşebilmesi,

- derslerin proje bazlı yürütülebilmesi,

- bilginin beceri ile entegrasyonu,

- disiplinlerarası çalışmaların önem kazanması,

- öğrencilerin ders seçimi konusunda tercih hakkının bulunması,

- öğrencilerin ilgi, merak, beceri ve yeteneklerine göre ders seçebilmesi ve bu doğrultuda bir kariyer planı yapılabilmesi.

$\mathrm{Bu}$ yeni sistemde temel olarak öğrenciyi kendisiyle buluşturmak amaçlanmıştır. $\mathrm{Bu}$ bağlamda öğrencinin ilgi, yetenek ve kişisel özellikleri doğrultusunda 21. yüzyıl becerileri bazında esnek bir yapı belirlenmiş ve bu alanlar kişisel rehberlik ve kariyer yönetimi mekanizmaları ile desteklenmiştir. Program çerçevesinde temel derslerden biri olarak kabul gören tarih dersleri için zorunlu şartı kaldırılmış, öğrencinin ilgisi doğrultusunda seçmeli derslere yer verilmiştir. Tarih derslerinin bu şekilde konumlandırılması branş öğretmenleri ve akademisyenler tarafından tartışmaya açılmıştır. Bu konuda yapılan tartışmalar bir başka makalenin konusu olmakla birlikte, tartışma odağına bilgi üretimi ve bilginin işlevsel olarak kullanabilme potansiyelinin alınmayışı eğitimin geleceği açısından bir başka soru işareti olarak karşımıza çıkmaktadır.

\section{Sonuç}

Son yıllarda eğitim politikalarının ana odağını 21. yüzyıl becerileri eksenli tartışmaların oluşturduğu ve bu tartışmaların genel çerçevesini Dünya Bankası, Dünya Ekonomik Forumu, OECD ve Avrupa Konseyi gibi uluslararası kurumlar tarafından yayınlanan iş dünyasının eğitim beklentilerine ilişkin raporların belirlediği görülmektedir. İlgili raporlarda bu sorunların odağının küresel ekonomi ve top-

\footnotetext{
${ }^{30}$ Ahmet Şimşek, “2017 Taslak Tarih 9-10-11, Türk Kültür Ve Medeniyet Tarihi Öğretim Programlarının Eleştirisi”, TUHED, 6/1 (2017), s.162.

31 "Hayal, Etkinlik, Yaşam".
} 
lumsal ihtiyaçlardan kopuk bir eğitim paradigması olduğunun altı çizilmektedir. Küreselleşme ve teknolojideki hızlı ilerlemeler sivil alanı ve çalışma dünyasını dönüştürmeye devam ederken, toplumsal gerçeklerin ve ihtiyaçların göz ardı edildiğine vurgu yapılan raporlarda sürdürülebilir global hedeflerle ilişkili kapsayıcı ve uyumlu eğitim politikalarının geliştirilmesinin ana şartının müfredatların 21. yüzyıl becerileriyle uyumlandırılmasından geçtiği kaydedilmektedir.

Özellikle Avrupa Konseyi tarafından yayınlanan Eğitimin Geleceği ve Becerileri2030 başlıklı raporda, eğitim sistemlerinde okutulan zorunlu ya da seçmeli tüm derslerin genel işlevlerinin yeniden sorgulanması gerekliliği dikkat çekmektedir. İlgili raporda mevcut müfredatların eleştirel bakış açısıyla sorgulandığı ve yeniden yorumlandığı görülmektedir. Bu inceleme süreci, "tarih eğitiminde ilerleme" konusu ile "bu ilerlemenin ölçülmesi" hususunu da bir problem olarak karşımıza çıkarmaktadır. Bu iki önemli sorunun çözülmesi konusunda tarihsel düşünme ve araştırma yöntemlerinin müfredatlara dahil edilmesi gerektiğinin altı çizilmektedir. Raporda, tarih eğitiminde ilerlemenin temel özellikleri olarak öğrencilerin analitik ve eleştirel düşünebilmeleri için bilişsel yeteneklerinde bir artışa işaret edilmekte ve öğretmenlerin derslerde öğrencilerinin bu kapasiteyi geliştirmeleri konusunda yöntemler geliştirmelerine olan gereksinim dile getirilmektedir.

Esasında müfredat programlarında resmi tarihyazımının izlerini taşıyan "resmi bilgi"nin tarih dersleri kanalı ile aktarımı konusu 1970'lerden itibaren belirginlik kazanan pedagojik araştırmalar, iletişim ve bilgi teknolojilerindeki gelişmeler, küreselleşme ve uluslararası rekabet ile insan hakları konusundaki çalışmalar ekseninde tartışılmaktadır. Bu tartışmalar Tarih eğitiminin niteliğinin de sorgulanması ile birlikte programların değişimine zemin hazırlamıştır. Bu çerçevede yapılan araştırmalarda resmi bilgi çerçevesinde hazırlanan derslerin öğrencilerin bireysel ve zihinsel olarak ilerleyişine engel oluşturduğu tespit edilmiştir. Bu gelişmeler, tarih eğitimine disiplinlerarası ve geniş perspektifli bir bakış açısı getirmiştir. Bu perspektiften ele alındığında, tarih öğretim programları özellikle son yıllarda tarihsel önem, kanıt, süreklilik ve değişim, neden sonuç, tarihsel bakış açılar1 ve etik boyutlarından oluşan kavramlara yer verildiği görülmektedir. Bu kavramlara ilave olarak tarihsel düşünme konulu çalışmalarda dijital malzemelerin de kullanımının teşvik edildiği yüksek kaliteli bir tarih anlayışına doğru gidildiği görülmektedir.

$\mathrm{Bu}$ şekillenmenin odağını tarih eğitiminde kalite ve ilerlemeye duyulan ihtiyaç oluşturmaktadır. Aynı zamanda bu ihtiyaç, geleneksel yaklaşımların nitelikten yoksun olduğu ve ilerlemeye ihtiyaç duymadığı kabulünü de beraberinde getirmektedir. Örneğin, Dünya Ekonomik Forumu Geleceğin Okulları: Dördüncü Sanayi Devrimi için Yeni Eğitim Modellerini Tanımlama başlıklı raporda, eğitim sistemlerindeki sorunlara dikkat çekilmekte ve ilgili raporda bu sorunların odağ1nı küresel ekonomi ve toplumsal ihtiyaçlardan kopuk bir eğitim paradigmasının oluşturduğu dile getirilmektedir. Küreselleşme ve teknolojideki hızlı ilerlemeler sivil alanı ve çalışma dünyasını dönüştürmeye devam ederken, toplumsal gerçeklerin ve ihtiyaçların göz ardı edildiğine vurgu yapılan raporda sürdürülebilir global hedeflerle ilişkili kapsayıcı ve uyumlu eğitim politikalarının geliştirilmesinin ana şartının müfredatların 21. yüzyıl becerileriyle uyumlandırılması zorunlulu- 
ğuna işaret edilmektedir. Tarih eğitimi konusunda yapılan araştırmalardan elde edilen bulgular da tarih müfredatlarının bu uyumu henüz karşılayamadığını, kaliteli bir gelecek inşa edebilmek için geçmişle ilgili çalışmaların da kaliteli bir şekilde eğitim sistemine entegre edilmesi gerektiğini dile getirmektedir. Bu bağlamda önerilen ve kabul gören modellerden biri de tarihsel düşünme becerileridir. Kanada, İngiltere, Avustralya ve ABD gibi refah seviyesi yüksek ülkelerin tarih müfredatlarında bu modelin benimsendiği tespit edilmiştir. Türkiye Tarih öğretim programlarında tarihsel düşünme becerileri ile ilişkili kavramların yer aldığı görülmekte ve ayrıca öğrencilerde bu becerilerin kazandırılması yönünde bir ihtiyaca da dikkat çekilmektedir.

Bu doğrultuda yürütülen çalışmalara gerek ulusal gerek ulusüstükurumlarca destek verildiği bilinmektedir. Özellikle son yıllarda Avrupa Konseyi tarafından yayınlanan tavsiye kararlarının dikkat çekici olduğu söylenebilir. Yine George Eckert Uluslararası Ders Kitapları Araştırma Enstitüsü (GE) ve Avrupa Tarih Eğitimcileri Birliği (EUROCLIO) gibi sivil toplum kuruluşlarının alana ilişkin uluslararası ve bölgesel projelerinin katma değer yarattığı görülmektedir. Benzer şekilde Avrupa Birliği Parlamentosu'nun da tarih alanındaki uluslararası ve bölgesel çalışmalara finansal destek verdiği görülmektedir.

$\mathrm{Bu}$ çerçevede resmi tarih bilgisinin müfredatlardan ayıklandığ kazanımlarının disiplinlerarası bir anlayış ile küresel riskler bağlamında yeniden yapılandırıldığı görülmektedir. Böylece tarih eğitiminde statik ulus tarih anlatısı modelinden, kalite kavramından bahsedilen dinamik bir sürece geçilebileceği düşünülmektedir. Bu sürecin özellikle tartışmalı ve hassas konularda "bilginin", eleştirel çerçevede analiz edilebilmesi ve yorumlanabilmesi için çok perspektifli ortamlar geliştirdiği söylenebilir. Ders içerikleri, 21. yüzyıl becerileri perspektifi ile desteklenmekte, kazanımlar eleştirel düşünme ve problem çözme becerileri ekseninde geliştirilmektedir. Tarihsel olaylara yaklaşımda ise çok perspektifliliğin benimsendiği ve kültürel mirasın ortak yönlerinin takdir edilmesi gibi amaçlar ile ilişkilendirildiği görülmektedir.

$\mathrm{Bu}$ açıdan değerlendirildiğinde tarih dersleri kanalıyla

- bilgisayar işlem teknolojileri ile çeşitli kategorilerdeki veri setlerinin yorumlanması ile geliştirildiği

- sinirbilimdeki gelişmeler ile anlatının sorgulanmasına yönelik çalışmaların yürütüldüğü,

- uzay-haritalama teknolojileri ile yeni alanların keşfine yönelik tarihsel materyal ve içeriklerinin geliştirildiği

- disiplinlerarası içerik ve uygulamalar ile proje bazlı çalışmaların teşvik edildiği,

- internet kullanımının yaygınlaşması ve sosyal medyanın günlük hayatın bir parçası haline gelmesi ile tarih pratiklerinin farklılaştığı,

- tarih derslerinde 21. yüzyıl becerilerinin etkisini taşıyan çalışmaların teşvik edildiği tarih eğitiminde gerçekten yeni bir sürece girildiği söylenebilir.

$\mathrm{Bu}$ süreci her kesimden insanın eğitim sistemine doğrudan katılabileceği demok- 
ratik bir süreç olarak tanımlamak da mümkündür. Teknolojik gelişmeler ekseninde ele alındığında, tarih eğitimi alanın, bu alanın eğitimci, politika geliştirici ve profesyonelleri ile doğal olarak disiplinlerarası bir ortaklık arayışını ve kalite anlayışını beraberinde getirmesi kaçınılmaz görünmektedir. Bu çerçevede hayata geçirilecek tarih programları ekseninde sadece global dünyanın gelecekten beklentileri olumlu yönde karşılanmayacak olup aynı zamanda ezberden ibaret ve sıkıcı olarak kabul gören tarih derslerinin de öğrencinin zihninde farklılaşacağı düşünülmektedir.

\section{Kaynakça}

“2023 Eğitim Vizyonu”. MEB. 2018. Erişim 1 Nisan, 2020. http://2023vizyonu.meb.gov.tr/.

Aktekin, Semih. Çev., "Yüksek Nitelikli Tarih, Kültürel Miras ve Vatandaşlık Eğitimi İçin Manifesto: Tarihin Genç Nesillerin Gelişiminde Ayırt Edici Katkısının Tanınmasına İlişkin 15 İlke”. TUHED, 8/2 (2019).

Altun, Adnan ve Bahri Ata. “UNESCO’nun Tarih Eğitimi Yayınlarına Yönelik Bir Değerlendirme 1947-2012”. Adıyaman Üniversitesi Sosyal Bilimler Enstitüsü Dergisi, 14 (2013).

“Annual Report”, The World Bank. Washington, 2016.

Apple, Michael W. M. Official Knowledge: Democratic Education in a Conservative Age. NY: Routledge, 1993.

Ata, Bahri. "Sosyal Bilgiler Eğitiminde İyi Bir Örnek: ABD Kongre Kütüphanesinin Amerikan Hafıza Projesi”. Türk Kütüphaneciliği. 25/2 (2011).

Ata, Bahri. “Tarih: İngiltere ve ABD’deki Tarih Eğitimi Araştırmalarını Toplu Bir Değerlendirme (1917-1950) - C. M. Fleming”. TUHED. 3/2 (2014).

"Australian Curriculum: Humanities and Social Sciences Learning Area Online". Erişim 01 Mart 2020. http://australiancurriculum.edu.au/f-10curriculum/humanities-and-social-sciences/.

"Better Policies for Better Lives: The OECD at 50 and Beyond". Paris: OECD Publishing, 2011.

"Better Skills Better Jobs Better Lives: A Strategic Approach to Skills Policies". Paris: OECD Publishing, 2011.

Binkley, M., O. Erstad, J. Hermna, S.Raizen, M. Ripley, M.Miller-Ricci, ve M. Rumble. "Defining Twenty-First Century Skills". Assessment and Teaching of 21st Century Skills, Der., P. Griffin, E. Care ve B. Dordrecht McGaw. Springer, 2012.

C., Husbands, A. Kitson ve A. Pendry. Understanding History Teaching. USA: Open University, 2003.

European Union. "Education and Training Monitor". 2012.

Gelen, İsmail. "P21-Program ve Öğretimde 21. Yüzyıl Beceri Çerçeveleri”. Disiplinlerarası Eğitim Araştırmaları Dergisi (Journal of Interdisciplinary Educational Research), 1/2 (2017): 15-29. 
"Global Challenge Insight Report: Future of Jobs". World Economic Forum. Geneva: Switzerland, 2016.

"Global Challenge Insight Report: Future of Jobs." World Economic Forum. Geneva: Switzerland, 2020.

"Global Economic Prospects". The World Bank. Washington, 2019.

"Global Economic Prospects". The World Bank. Washington, 2017.

"Global Economic Prospects". The World Bank. Washington, 2018.

Green School High School Curriculum. https://www.greenschool.org/bali/wpcontent/uploads/sites/2/2019/10/Green-School-High-School-CurriculumOverview-2019-2020.pdf. (erişim 01.08.2020).

“Hayal, Etkinlik, Yaşam” ERG Eğitimin İçeriği Eğitim İzleme Raporu 2019. Erişim 25 Mayıs 2019. https://www.egitimreformugirisimi.org/wpcontent/uploads/2010/01/EIR_Egitimin_Icerigi.pdf.

"Historical Thinking Skills". WHRHS. Erişim 08 Mayıs 2020. https://www.whrhs.org/uploaded/Social_Studies/Historical_Thinking_Skills. pdf 2014.

"How To Use Online Tools to Promote Historical Thinking: Historiana Historical Education Team". European Association of History Educators, 3 (2020).

"Improving Competences for The 21st Century: An Agenda for European Cooperation for Schools.” European Union. Luxemburg, Belgium. 2008.

"The Ontario Curriculum for Social Studies, History and Geography”. Erişim 01 Mart https://curriculum.gov.bc.ca/sites/curriculum.gov.bc.ca/files/curriculum/soci al-studies/en_social-studies_k-9_elab.pdf.

"Key Competences for Lifelong Learning European Reference Framework" European Union. Luxemburg, Belgium. 2006.

"Medium-Term Strategy" 2014-2021. UNESCO General Conference. 37th, 20132014.

"National Curriculum in England: History programmes of study Online. Erişim 01 Mart 2020. www.gov.uk/government/publications/national-curriculumin-england-history- programmes-of-study

“P21”. Erişim 1 Mart 2020. https://www.battelleforkids.org/networks/p21.

"Proposal For A Council Recommendation on Key Competences for LifeLong Learning. European Union”. Luxemburg, Belgium. 2018.

Rychen, D. S. ve L. H. Salganik, Der. "Key Competencies for a Successful Life and a Well-Functioning Society". DeSeCo's Final Report. Göttingen: Hogrefe \& Huber Publishers, 2003.

Schleicher, Andreas. The Case for 21st Century Learning. OECD. Paris, 2009. http://www.oecd.org/general/thecasefor21st-centurylearning.htm.

Seixas, P. ve T. Morton. "The Big Six Historical Thinking Concepts". Nelson College Indigenous, 2003.

"Schools of the Future Defining New Models of Education for the Fourth Industrial Revolution." World Economic Forum. Geneva: Switzerland, 2019. 
"Skills for Social Progress: The Power of Social and Emotional Skills", OECD Publishing, Paris. 2015.

"Strategic Framework for European Cooperation in Education and Training". European Union. Luxemburg, Belgium. 2009.

Şimşek, Ahmet ve Fatih Yazıcı. “Türkiye'de Tarih Öğretiminin Dünü, Bugünü”. TYB Dil Edebiyat ve Sosyal Bilimler Dergisi, 3 (2013).

Şimşek, Ahmet ve Sibel Yalı, Gerçekten Öyle Mi Olmuş? Post-Truth Zamanlarda Tarihin Temsili. İstanbul: Yeni İnsan, 2019.

Şimşek, Ahmet. “2017 Taslak Tarih 9-10-11, Türk Kültür Ve Medeniyet Tarihi Öğretim Programlarının Eleştirisi”. TUHED, 6/1 (2017).

Tekeli, İlhan. Birlikte Yazılan ve Öğrenilen Bir Tarihe Doğru. İstanbul: Tarih Vakf1, 2007.

"The Definitions and Selection of Key Competencies: Executive Summary". OECD Publishing, Paris: 2005.

“The Future of Education and Skills, Education 2030". Erişim 01 Ağustos 2020. https://www.oecd.org/ education/ 2030-project /contact/ E2030_Position_Paper_(05.04.2018).pdf.

The Dakar Framework for Action: Education for All: Meeting our Collective Commitments. UNESCO. Paris, 2000.

Turan, İbrahim. “Thematic vs Chronological History Teaching Debate: A Social Media Research". Journal of Education and Learning, 9/1 (2020).

"UCLA History Standarts" UCLA Online. Erişim 10 Nisan 2020. https://phi.history.ucla.edu/nchs/history-standards/.

UNESCO. "Futures of Education". Erişim 01 Eylül 2020. https://en.unesco.org/futuresofeducation/2019.

Van Drie, Jannet ve Carla van Boxtel. "Historical Reasoning: Towards a Framework for Analyzing Students' Reasoning About the Past”. Educational Psychology Review, 20/2 (2008).

Video of Andreas Schleicher (OECD) On Quality and Equity in Education at the Australian Council for Educational Research 2014 Conference: http://www.acer.edu.au/rc.

Yalçın, Seher. "21. Yüzyıl Becerileri ve Bu Becerilerin Ölçülmesinde Kullanılan Araçlar ve Yaklaşımlar”, Ankara Üniv. Eğitim Bilimleri Fakültesi Dergisi, 51/1 (2018).

Yalı, Sibel. “Tarih Öğretimine Yeni Bir Yaklaşım: Büyük Tarih Projesi”. Turkish History Education Journal, 8/2 (2019).

Yalı, Sibel. “Tavsiye Kararları Çerçevesinde Avrupa Konseyi’nin Tarih Öğretimi Vizyonu”. Türk Tarih Ĕ̈itimi Dergisi, 5/2 (2016).

Yalı, Sibel. “Avrupa'da Tarih Eğitimi ve Öğretimine Yönelik Girişimler ve Avrupa Birliği'nin Katkısı”. Fırat Üniv. Sosyal Bilimler Dergisi. 26/1 (2016).

Yalı, Sibel "Bir Ütopya Analizi: Avrupa Birliği Okullarda Tarih Öğretimine Sponsor Olabilir mi?”. Türk Tarih Eğitimi Dergisi. 6/1 (2017).

Yalı, Sibel. Çev., “Tarihsel Düşünme Kriterleri: Kanada Ölçme-Değerlendirme Sistemi İçin Bir Çerçeve”. TUHED. 7/1 (2018). 
Yalı, Sibel. Çev., "21. Yüzyılda Kaliteli Tarih Eğitimi: Prensipler ve Kılavuzlar”. TUHED, 8/1 (2019).

Yazıcı, Fatih ve Ahmet Şimşek. "Tarih Öğretiminde Nesnellik Sorunu”. Tarih Okulu Dergisi, 11 (2012).

Yılmaz, Kaya. "Postmodernist Tarih Yaklaşımı: Postmodernizmin Tarih Eğitimi İçin Doğurguları”. Pamukkale Üniv. Eğitim Fakültesi Dergisi, 34 (2013).

Zarmatı, Louise. "Eğitimin ve Becerilerin Geleceği 2030: Müfredat Analizi Tarih Eğitiminde İlerleme”. TUHED, 9/1 (2020). 


\title{
Conceptual Direction of History Teaching from the Perspective of 21st Century Skills
}

\author{
SiBEL YALI
}

Abstract: In this study, current date curriculums - both from Turkey and also from countries with high levels of welfare, such as Canada, UK, Australia, United States - were reviewed from the perspective of the 21st century skills, in order to determine how history education changes according to the conjuncture. In this context, a general framework about 21st century skills was presented, and then the reflections of this approach in history education were emphasized. The last part of the study attempts to develop an interpretation, based on history education practices from Turkey and other countries in scope. By the millennium, especially in countries with high welfare, it is seen that gains from history education is associated with critical thinking and problem solving skills; multi-perspectivity approach to historical events is developed, and efforts are made to appreciate the common aspects of cultural heritage. In this context, current curricula prepared for history and social studies courses in Canada, Australia, England and United States provide a subject-specific perspective. For Turkey, it may be said that there is still a way to be taken in terms of practices.

Keywords: History education, Education policies, 21st Century skills 